\title{
Facilitating Students' Attitude in the Concept of Heat Energy in Nigerian Senior Secondary School Physics Using Models, Realia and Instructional Charts
}

\author{
Akinbobola, A. O. \& G. A. Ikitde
}

\begin{abstract}
This study investigated the facilitating effect of models, realia and charts on students' attitude in teaching the concept of heat energy in Nigerian senior secondary school Physics. A total of 183 senior secondary two (SS2) Physics students constituted the sample. This study adopted quasi-experimental design in 4 co-educational secondary schools in Ife South Local Government Area of Osun State, Nigeria. Physics Attitude Scale (PAS) was used to collect the data and the coefficient of internal consistency for PAS was 0.85 using Cronbach alpha. The data collected were analyzed using Analysis of Covariance. The results showed that models were the most effective in facilitating students' attitude towards leaning Physics. This was then followed by realia while charts were found to be the least effective in facilitating students' attitude towards Physics learning. The results also showed an insignificant gender difference in the attitude of students towards Physics when taught with models, realia and charts. The results also indicated that the facilitating effect of instructional materials on students' attitude towards Physics is not the same at all levels of gender. It is recommended that charts should be used together with models/realia materials for the main lesson, revision and reference purposes.
\end{abstract}

Key Words: Attitude, Heat Energy, Realia, Models, Charts.

\section{Introduction}

Attitude is viewed as the evaluative dimension of concept and is acquired through learning and can be changed through persuasion using variety of techniques. Attitude can also be described as a state of readiness, a tendency on the part of individual to act in a certain way (Adesina and Akinbobola, 2005). In Nigeria, Alao (1985) showed that attitude to any of the basic sciences, Physic, Chemistry and Biology is positively correlated to performance in the science subjects. Ogunleye (1999) reported in a study that many students developed negative 
attitude to science learning, probably due to the fact that teachers are unable to satisfy their aspirations or goals.

Teachers use several approaches to influence effective teaching and learning. Among such approaches include the use of different instructional materials to motivate learning in different subjects. The instructional materials that are commonly available are the chalkboard, textbooks, charts, models, posters, realia, graphs, as well as other improvised materials (Awotua-Efebo, 2001). One of the effective approaches adopted by teachers to discharge their duty in the classroom is to select and use appropriate instructional charts, models, and realia materials to make the lesson more meaningful and understandable.

Okwo and Ike (1995) described instructional materials as aids to effective teaching in the classroom which evoke in students the same mental image as in the teacher, thereby making words more comprehensible or less ambiguous and providing a common starting point to get the class thinking along similar lines. They include chalkboard, real objects, models, mockups, pictures, charts, television, typewriters, slide filmstrip and short form cards.

Instructional materials may be classified into two according to production categories. These are local instructional materials, which are locally produced or improvised, and commercial instructional materials, which are commercially produced or imported. Local instructional materials are materials obtained from the environment that are useful in the teaching and learning process, which are produced by the students, the teachers or both, with or without the help of a resource person. They are real objects (realia) or representations which teachers use to teach more effectively and these include real objects, charts, graphs, specimens and models which can either be of two or three dimensional objects (Akinbobola, 2005).

In whatever manner they are defined, instructional materials have the property of improving the teaching and learning process for both the 
students and the teachers. This applies to all instructional materials generally but each particular type is also unique in the type of experience it exposes the students to and skills it may develop in the students.

Realia refers to real things and objects presented in actual conditions which may include tools, life specimen, coins, artifacts, samples, relics, souvenirs, dioramas, plants and animals. Realia materials offer a reality of experience, which are not easily obtained through other materials and contribute to the efficiency, depth and variety of learning, which stimulate self-activity on the part of pupils (IbeBassey, 2000).

A model is a three dimensional representation of a real object which may be complete in every detail or considerably more simplified than the original (Onyejemezi, 1991). Realia and models possess threedimensional surfaces which are subject to great manipulation through observation, hearing, touching and experimentation. Realia and models generally portray the cultural heritage of the people. The technology evolved by the people in the solution of their day-to-day problems emanates from the use of such cultural resources like realia and models in the teaching/learning processes (Onyejemezi, 1991).

Instructional charts are graphical and pictorial representations of concepts, phenomena, or materials meant for instructional purposes. Roberts (1998) found out that charts help focus the minds of the students on what is taught apart from being an aid to memory. Students learn better and faster when they are taught with adequate visual aids like charts, pictures or posters than when they are left to wallow in abstract imaginations. Charts if properly manipulated and utilized create a situation or atmosphere in which curiosity is aroused, imagination stimulated, interest generated and view changed. Generally, instructional materials make teaching easy and productive because learners participate actively in the lesson and this participation develops the learner interest, attention, and positive attitudes and finally motivates them. 


\section{Statement of the Problem}

In view of the current harsh economic realities in Nigeria, and the high cost of standard science equipment and materials, it has become virtually impossible to provide science facilities and equipment for any meaningful student hands-on activities in schools by the government. Consequently, the problem faced by science teachers in Nigeria is not only what to teach, but how to teach. As a result certain scientific concepts have been tagged "difficult concepts" simply because either the teachers find such concepts difficult to teach or the students find them difficult to learn. Based on the above premise, some students who have developed much phobia for Physics are consequently showing lack of interest, poor attitude and generally poor academic performance in Physics examination. Hence, could models and charts be an appropriate substitute for realia in teaching various concepts in Physics and will there be any appreciable positive change in the attitude of students towards Physics when they are taught with models, realia and charts? These are the questions that have necessitated the investigation of the effects of models, realia and charts on students' attitude towards Physics.

\section{Purpose of the Study}

The purpose of this study is to determine the effect of models, realia and charts on students' attitude in the concept of heat energy in Nigerian senior secondary school Physics. Specifically the study seeks:

1. To ascertain the effects of instructional materials (models, realia and charts) on students' attitude towards Physics.

2. To compare the attitude of male and female Physics students taught with instructional materials (models, realia and charts).

3. To investigate the interaction effects of instructional materials and gender on students' attitude towards Physics.

\section{Research Hypotheses}

The following hypotheses were formulated and tested at .05 level of significance. 
$\mathbf{H}_{\mathbf{0}}$ 1: There is no significant difference in the attitude of Physics students taught with models, realia, charts and those taught without instructional materials.

Ho 2: There is no significant difference in the attitude of male and female Physics students taught with models, realia, charts and those taught without instructional materials.

$\mathbf{H}_{\mathbf{0}}$ 3: There is no significant interaction effect of instructional materials and gender on students' attitude towards Physics.

\section{Research Method}

The research design adopted for the study was Quasi-experimental design. All the 750 Senior Secondary Two (SSII) Physics students in all the thirteen (13) co-educational secondary schools in 2005/2006 academic session in Ife South Local Government Area of Osun State, Nigeria constituted the population.

A total of 183 Physics students took part in the study. Criterion sampling technique was used to select schools from the population. The criteria are:

i. Schools that have at least one professional graduate Physics teacher with at least five years of teaching experience.

ii. Schools that have well equipped and functional Physics laboratories.

iii. Schools that are currently presenting candidates for the Senior Secondary School Certificate Examination (SSCE).

Eight (8) schools met the above criteria. Four (4) schools were randomly selected from the schools that met the above criteria through the use of balloting. The four schools were randomly assigned to treatment and control groups. Three (3) out of four (4) schools were used as experimental group while one (1) school was used as control group. 
Physics Attitude Scale (PAS) was the instrument used for data collection. The PAS was developed by the researcher and was used to measure the attitude of Physics students towards the instructional materials used in the study. The PAS comprised 25 items on four (4)point rating scale responses of Strongly Agree (SA), Agree (A), Disagree (D) and Strongly Disagree (SD) and were assigned the value points of 4, 3,2, and 1 respectively for positive statements. The values were in reverse order for negative statements. Two educational psychologists and two Physics experts ascertained the validity of PAS. The PAS was trial tested to establish its reliability with 40 subjects in a school that was not used for the main study but was part of the population. Cronbach alpha was used to obtain the reliability coefficient of PAS and the coefficient of internal consistency of the PAS was 0.85 .

Teacher quality factors were ensured by using the Physics teachers in each school that served as research assistants to teach the concept of heat energy to their respective subjects. The research assistants were well trained for two weeks on how to use various instructional materials and they were given detailed instructions with wellarticulated lesson packages on how to teach each group with the instructional materials on the concept of heat energy. Pre-attitude questionnaire was administered to the experimental and control groups prior to the treatment given to the experimental group and the results were used as covariate measures in order to account for possible pre-existing differences in the overall ability between the groups. After the administration of the pre-attitude questionnaire, treatments were given to the experimental group. The experimental group 1 was taught the concepts of specific heat capacity and latent heat with realia. The apparatus consisted of a lagged copper calorimeter, a solid copper, two thermometers, a Bunsen burner, a beaker, water, a tripod stand, wire gauze and a supply of ice and water. The experimental group 2 was taught the same concepts with models. The subjects were involved in the procurement of the materials that served as models. Tins were used as models for 
calorimeter and beaker, and aluminium rod was used as a stirrer. The experimental group 3 was taught the same concepts with charts. The control group was taught the same concepts without instructional materials. The experimental and control groups were taught the concepts of heat energy using the same content outline for four weeks. After the treatment, post attitude questionnaire was administered to the two groups. The data collected were analyzed using Analysis of Covariance (ANCOVA) using pre-attitude scores as covariates. All hypotheses were tested at .05 level of significance.

\section{Results}

\section{Hypothesis One}

There is no significant difference in the attitude of Physics students taught with models, realia, charts and those taught without instructional materials. The analysis is presented in Table 1.

Table 1 shows that the main effect was significant at $\mathrm{P}<.05$. The calculated F-value of 18.74 is greater than the critical F-value of 2.65, thus the null hypothesis stating a non-significant difference in the attitude of Physics students taught with models, realia, charts and those taught without instructional materials was rejected. Since the ANCOVA analysis showed a significant difference between the treatment groups, further analysis were performed using multiple classification analysis in order to determine which of the instructional materials contributed to the gain in students' attitude towards the concept of heat energy in Physics as shown in Table 2.

The analysis in Table 2 shows a multiple regression index $(\mathrm{R})$ of .80 with a multiple regression-squared index $\left(\mathrm{R}^{2}\right)$ of .64 . This means that $64 \%$ of the total variance in the attitude of students towards the concept of heat energy in Physics is attributable to the influence of instructional materials. To find the order of effectiveness of instructional materials and direction of significance under investigation, the post attitude scores were subjected to Scheffe multiple comparison test for a post hoc analysis. The mean difference 
between models and realia was 6.84 ; between models and charts was 13.26; between models and WIM was 26.08; between realia and charts was 6.43 ; between realia and WIM was 19.25 and between charts and WIM was 12.82. This means that models was the most effective in facilitating students' attitude towards the concept of heat energy in Physics. This is seconded by realia, followed by charts while the non-instructional material was seen to be the least effective in facilitating students' attitude towards the concept of heat energy in Physics.

\section{Hypothesis Two}

There is no significant difference in the attitude of male and female Physics students taught with models, realia, charts and those taught without instructional materials. The analysis is as shown in Table 3. As shown from Table 3, the gender main effect was not significant at $\mathrm{P}<.05$ where the calculated F-value of 0.02 is less than the critical value of 3.90. Thus, the null hypothesis stating a non-significant difference in the attitude of male and female Physics students taught with models, realia, charts and those taught without instructional materials was retained.

\section{Hypothesis Three}

There is no significant interaction effect of instructional materials and gender on students' attitude towards Physics. The analysis is presented in Table 3. As shown in Table 3, the interaction between the instructional materials and gender was found significant at $\mathrm{P}<.05$ where the calculated F-value of 3.62 is greater than the critical F-value of 2.66. Therefore, the null hypothesis stating a non-significant interaction effect of instructional materials and gender on students' attitude towards Physics was rejected. This means that the facilitating effect of instructional materials on students' attitude towards Physics is not the same at all levels of gender. 


\section{Discussion}

The results of hypothesis one indicated that there was a significant difference in the attitude of Physics students taught with models, realia, charts and those taught without instructional materials. The findings also showed that $64 \%$ of the total variance in the attitude of students towards the concept of heat energy in Physics is attributable to the influence of instructional materials used in teaching the students. The results also showed that models were the most effective in facilitating students' attitude towards the concept of heat energy in Physics. This is seconded by realia, followed by charts while the noninstructional material was seen to be the least effective in facilitating students' attitude towards the concept of heat energy in Physics. This might be due to the fact that when instructional materials are effectively utilized by the teacher in his lessons, and are directly related to the facts, students are interested and they develop positive attitude towards the concepts being taught. The poor attitude in the chart group might be due to its non-manipulation and students inactiveness in class participation. This is in line with the findings of Ibe-Bassey (2000) that instructional materials like models and realia are used to provide direct, concrete and purposeful learning experiences. He further noted that model and realia make teaching easy and productive because learners participate actively in the lesson and this participation develops in the learner interest, attention, positive attitudes and finally motivates them. This is also consistent with the findings of Onyejemezi (1991) that instructional materials help students focus attention on specifics, arouse curiosity and help sustain interest and attention.

The results of hypothesis two showed that there was no significant difference in the attitude of male and female Physics students taught with models, realia, charts and those taught without instructional materials. This might be due to the fact that the use of charts, realia and models materials in teaching both boys and girls provide them with the opportunity to listen to the teacher, observe activities, ask and answer relevant questions as well as have privilege of practising the 
task involved in the concept with the view of acquiring the necessary skills required through manipulation and perfecting on the tasks and hence developing positive attitude towards the subject. This is consistent with the findings of Leinhardt (1999) that shows no significant difference attributed in the mean performance and attitude between boys and girls in the manipulation of the same instructional materials as well as in their rate of contribution and class participation.

The results of hypothesis three indicated a significant interaction effect of instructional materials and gender on students' attitude towards Physics. This implies that the facilitating effect of instructional materials on students' attitude towards Physics is not the same at all levels of gender.

\section{Conclusion}

In the light of the findings of this study, the researchers conclude that instructional materials used in teaching the concepts of heat energy enhanced the attitude of students towards Physics. Models were the most effective in enhancing students' attitude towards Physics learning. This was then followed by realia while charts were found to be the least in enhancing students' attitude towards Physics learning. The results also showed an insignificant gender difference in the attitude of students towards Physics when taught with models, realia and charts. The results also indicated a significant interaction effect of instructional materials (models, realia and charts) and gender on students' attitude towards Physics. This implies that the facilitating effect of instructional materials on students' attitude towards Physics is not the same at all levels of gender.

\section{Recommendations}

Consequent upon the findings of this study, it is hereby recommended that: 
- Physics teachers should adopt the use of models in the teaching of various concepts in Physics in order to facilitate students' attitude towards Physics.

- Charts can be used together with realia/models materials for the main lesson, revision and reference purpose. Through careful integration of charts and realia/models materials the students develop both mental and manipulative skills and therefore enhance students' attitude towards Physics.

- Seminars, conferences and workshops should be organized regularly for Physics teachers to broaden their knowledge on the use of charts, models and realia and get them involved in the processes and usage of inexpensive, local materials from the environment for making models in order to enhance teaching and learning processes.

\section{References}

Adesina, A. D. \& Akinbobola, A. O. (2005). "The Attitude of Students towards Part-time Degree Programme of the Faculty of Education, Obafemi Awolowo University, Ile-Ife." Journal of Research in Education, 2 (1), 1 - 4.

Akinbobola, A. O. (2005). "Effects of Realia and Charts on Academic Performance of Secondary School Students in Physics." Ife Journal of Theory and Research in Education, 9 (1), 23 - 32.

Alao, E. O. (1990). "A scale for Measuring Secondary School Students' Attitudes towards Physics." Journal of Science Teachers Association of Nigeria, 26 (2), 75 - 80.

Awotua-Efebo, E. B. (2001). Effective Teaching: Principles and Practice. Port Harcourt: Paragraphics.

Ibe-Bassey, G. S. (2000). Principles and Practice of Instructional Communications. Uyo: Dorand Publishers.

Leinhardt, G. (1999). "Learning what is Taught: Sex Difference in Instruction and Use of Teaching Aids." Journal of Educational Psychology, 71 (4), 432 - 439. 
Facilitating Students' Attitude in the Concept of Heat Energy...

Ogunleye, A. O. (1999). Science Education of Nigeria: Historical Development, Curriculum Futures and Research. Ibadan: Town Publishers.

Okwo, F. A. \& Ike, G. A. (1995). Educational Technology: Basic Concepts and Issues. Nsukka: University Trust Publisher.

Onyejemezi, D. A. (1991). Trends and Research in Educational Technology. Ibadan: Books Nig. Ltd.

Roberts, J. (1998). Effective Teaching Procedure. London: Oxford University Press.

Table 1: Analysis of Covariance (ANCOVA) of post-attitude scores of students taught with models, realia, charts and those taught without instructional materials using pre-attitude scores as covariates.

\begin{tabular}{lllllll}
\hline Source of Variation & $\begin{array}{l}\text { Sum of } \\
\text { Squares }\end{array}$ & DF & $\begin{array}{l}\text { Mean } \\
\text { Square }\end{array}$ & F-cal. & $\begin{array}{l}\text { F- } \\
\text { critical }\end{array}$ & $\begin{array}{l}\text { Decision } \\
\text { at } \mathbf{P}<.05\end{array}$ \\
\hline Covariates-Pre-attitude & 19113.47 & 1 & 19113.47 & 256.62 & 3.89 & $*$ \\
Main Effects & 4187.72 & 3 & 1395.91 & 18.74 & 2.65 & $*$ \\
Explained & 23301.18 & 4 & 5825.30 & 78.21 & 2.41 & $*$ \\
Residual & 13332.42 & 179 & 74.48 & & & \\
Total & 36633.60 & 183 & 200.18 & & & \\
\hline
\end{tabular}

* = Significant at $\mathrm{P}<.05 \quad$ F-cal. $=\mathrm{F}-$ calculated 
Table 2: Multiple classification analysis of post-attitude scores of students taught with models, realia, charts and those taught without instructional materials

\begin{tabular}{|c|c|c|c|c|c|}
\hline \multirow{2}{*}{$\begin{array}{l}\text { Grand Mean = } 61.86 \\
\text { Variable + Category }\end{array}$} & \multirow[t]{2}{*}{$\mathbf{N}$} & \multicolumn{2}{|c|}{ Unadjusted } & \multicolumn{2}{|c|}{$\begin{array}{l}\text { Adjusted for Independent } \\
\text { Variable and Covariate }\end{array}$} \\
\hline & & Dev'n & Eta & $\begin{array}{c}\text { Dev' } \\
\text { n }\end{array}$ & Beta \\
\hline INSTRUCTIONAL MATERIALS & & & .68 & & .39 \\
\hline Models & 47 & 11.26 & & 6.82 & \\
\hline Realia & 48 & 4.43 & & .93 & \\
\hline Charts & 45 & -2.00 & & .53 & \\
\hline Without Instructional Materials & 43 & -14.82 & & $\begin{array}{c}- \\
8.84\end{array}$ & \\
\hline $\begin{array}{l}\text { Multiple R. }=.80 \\
\text { Multiple R. Squared }=.64\end{array}$ & & & & & \\
\hline
\end{tabular}

Table 3: 2 x 4 Factorial Analysis of Covariance (ANCOVA) on students' attitude towards Physics under different instructional materials by gender using pre-attitude scores as covariates

\begin{tabular}{lcccccl}
\hline \multicolumn{1}{c}{$\begin{array}{c}\text { Source of } \\
\text { Variation }\end{array}$} & $\begin{array}{l}\text { Sum of } \\
\text { Squares }\end{array}$ & DF & $\begin{array}{l}\text { Mean } \\
\text { Square }\end{array}$ & F-cal. & F-critical & $\begin{array}{l}\text { Decision at } \\
\text { P<.05 }\end{array}$ \\
\hline Pre-attitude & 19113.47 & 1 & 19113.47 & 266.47 & 3.90 & $*$ \\
Main Effects & 4188.90 & 4 & 1047.23 & 14.60 & 2.42 & $*$ \\
Gender & 1.19 & 1 & 1.19 & 0.02 & 3.90 & NS \\
Instructional Materials & 4183.12 & 3 & 1394.37 & 19.44 & 2.66 & $*$ \\
2- Way Interactions & & & & & & \\
Gender X Inst - Mat & 778.77 & 3 & 259.59 & 3.62 & 2.66 & $*$ \\
$\begin{array}{l}\text { Explained } \\
\text { Residual }\end{array}$ & 24081.14 & 8 & 3010.14 & 41.73 & 1.99 & $*$ \\
Total & 12552.46 & 175 & 71.73 & & & \\
\hline
\end{tabular}

* = Significant at $\mathrm{P}<.05$ alpha level

$\mathrm{NS}=$ Not significant at $\mathrm{P}<.05$ alpha level

Inst - Mat $=$ Instructional materials 